\section{Opeshko N., Hontar D., Kovalchuk V.}

\title{
IMPROVING THE ASSESSMENT OF THE NON-LIFE INSURANCE MARKET DEVELOPMENT LEVEL IN UKRAINE
}

Розглянуто особливості функціонування страховик компаній в Україні, що здійснюють страхування інше, ніж страхування життя. Здійснено аналіз національного страхового ринку за 2005-2015 рр., що дозволило визначити основні проблеми його розвитку. Для оцінки рівня розвитку страхового ринку обрано 14 показників. 3 використанням кореляційного аналізу усунена мультиколінеарність між обраними показниками. Розраховано інтегральний показник рівня розвитку страхового ринку України із застосуванням методу таксономії.

ключові слова: страховий ринок, фінансова безпека, страховий портфель, рентабельність страхової діяльності.

\section{Introduction}

The non-life insurance market in Ukraine is on the stage of development. Becoming of the non-life insurance market in Ukraine, its further successful development will depend on many factors related to the sphere of production, by the level of welfare of population and other factors. The gradual development of the non-life insurance market in Ukraine necessitates studying its tendencies and characteristics that are important for an effective functioning of not only the economy but also the entire society and its social welfare. For this reason, the main aim of the work is an assessment of the non-life insurance market development level in Ukraine, exposure of its features characteristic to the modern stage of development of the national economy.

\section{The object of research and its technological audit}

In Ukraine, some problems of the insurance market are covered in the reports of the National commission that carries out government control in the field of the markets of financial services [1]. However, a single methodological approach to assess the level of the insurance market development in Ukraine is not developed. Therefore it is necessary to analyze and introduce the experience of international organizations that are engaged in research of the insurance market, including audit and consulting company «Ernst \& Young» [2], European insurance and reinsurance federation «Insurance Europe» [3], European Insurance and Occupational Pensions Authority (EIOPA) [4], Insurance information institute [5] etc.

\section{The aim and objectives of research}

The aim of research is assessing the non-life insurance market development level in Ukraine.

To achieve the objectives of the study authors define the following research objectives:

1. To consider the peculiarities of the insurer companies in Ukraine that carry out insurance other, than life-insurance.

2. To analyze the national non-life insurance market.
3. To select the indexes of assessing the non-life insurance market development level.

4. To eliminate the multicollinearity between selected parameters.

5. To calculate the integral indicator of the non-life insurance market development level in Ukraine.

\section{Research of existing solutions of the problem}

Scientist [6] investigated the impact of government regulation on the insurance market development level. In the research [7] the basic performance indicators of the insurance market in Ukraine (gross insurance bonuses, gross insurance payments, volume of money that is prepaid on reinsurance, volume of the insurance reserves) are analyzed and the row of measures is offered for providing its further development. The state, tendencies and problems of national insurance market development are described in the monograph [8]. Scientist [9] offered the strategy of development of postcrisis insurance market in Ukraine by two scenarios: inertia post-crisis insurance market development, modernization of the insurance market. The basic indexes that characterize the use of insurance as an effective instrument of insurance defense of the state and measures necessary for providing of effective insurance market in Ukraine are analyzed in the work [10]. Scientists [11-14] examined the causal relationship between insurance penetration and economic growth in different countries. In the paper [15] the factors affecting the insurance sector development were explored.

Despite the considerable amount of researches of Ukrainian and foreign scientists on the subject of the article, the methodical providing of assessment of the non-life insurance market development is not enough researched, in particular, there is a need to develop an integral index of the level of the non-life insurance market development and its scale measuring.

\section{Methods of research}

To achieve the objectives author used the following methods: analysis and synthesis, logic synthesis, graphical method, correlation and taxonomic analysis. 


\section{Research results}

From data of the National commission that carries out government control in the field of the markets of financial services [1], during the last decade the popularity of insurance as a financial instrument of defense of property interests of physical and legal persons grew considerably. The basic results of research are presented by next data. In Fig. 1 the dynamics of amount of the non-life insurance companies during 2005-2015 is represented.

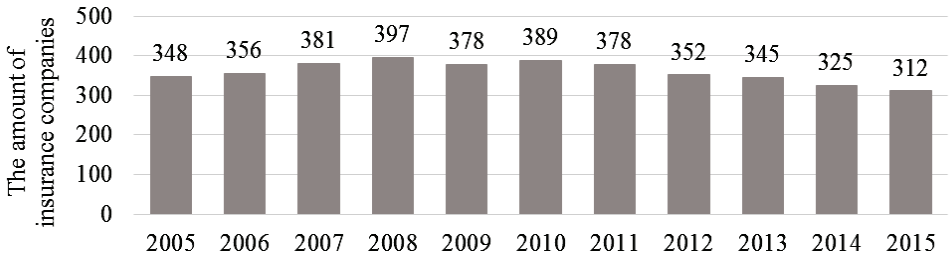

Fig. 1. The dynamics of amount of the non-life insurance companies performing insurance other than life insurance accidents caused by changing the activity of transporters and users of land and water transport in Ukraine. Regarding the volume of insurance premiums on insurance contracts, the most important indicator of this index was in 2010 due to increase of volume of the responsibility accepted by insurance companies on the contracts of aviation insurance of civil aviation. The dynamics of the average amount of the sum insured for each insurance contract during the studied period is unstable, so the biggest value this index attained in 2010 due to the rapid increase of the insurance liability and in 2014 due to the decrease in the number of insurance agreements.

The main indicators used in assessing the level of development of the non-life insurance companies at the macro level are the dynamics of gross and net premium, and the ratio of insurers' equity to GDP. The results of the calculation of key macroeconomic indicators of the non-life insurance market in Ukraine are presented in Table 2.
As shown in the Fig. 1, in 2007 the number of the non-life insurance companies that had the right to provide insurance services other than life insurance in Ukraine has increased significantly compared to the previous years (from 348 in 2005 and 356 in 2006 to 381 companies in 2007). This contributed to an increase in demand for insurance services through increased awareness about insurance among the population. In the following year, despite the start of the financial crisis the increase of the number of the non-life insurance companies also continued - to 397 and in 2009 this figure decreased and was 378. In 2010 the growth of the number of insurers recovered (from 378 to 389 companies). During 2011-2015 the number of insurance companies gradually decreased at the end of 2015 there were 312 insurers in Ukraine. The rapid decrease in the number of insurance companies for the last three years caused by financial crisis related to the annexation of the Crimea and the armed conflict in the eastern Ukraine. Due to the overall economic decline, the ability of insurers to fulfill their obligations decreased significantly, resulting increasing consumer complaints about insurance companies to National commission that carries out government control in the field of the markets of financial services [1], cancellation of licenses of financial institutions to conduct insurance business and their exclusion from the state register.

Table 1 shows the dynamics of the number of the nonlife insurance agreements and total responsibility for them during 2008-2015.

As shown in the Table 1, the largest amount of insurance contracts were in 2008, in further the amount of insurance contracts declined, and in 2014 it reached a critical size (19.76\% from that of 2008). Such tendencies are the amounts of concluded contracts of the obligatory personal insurance against transport accidents. Such index, as an amount of concluded contracts, is specific in this type of obligatory insurance, because its considerable value turns out in connection due to the fact that insurance is expected after buying the ticket and the number of people who daily use the land and water transport is very significant. That is why the dynamics of the number of contracts on compulsory insurance against transport
Table 1

Dynamics of the number of the non-life insurance agreements and the total amount of insurance premiums

\begin{tabular}{|c|c|c|c|}
\hline Year & $\begin{array}{c}\text { The amount } \\
\text { of insurance } \\
\text { agreements }\end{array}$ & $\begin{array}{c}\text { The total amount of liabi- } \\
\text { lity (insurance premiums) } \\
\text { under insurance agree- } \\
\text { ments, mln UAH }\end{array}$ & $\begin{array}{c}\text { The average sum } \\
\text { insured for each } \\
\text { insurance contract, } \\
\text { ths UAH }\end{array}$ \\
\hline $2008^{*}$ & 675178510 & 9404823.96 & 13.93 \\
\hline 2009 & 574646850 & 50115148.74 & 87.21 \\
\hline 2010 & 618545339 & 141339537.16 & 228.5 \\
\hline 2011 & 616705003 & 17547449.74 & 28.45 \\
\hline 2012 & 175683397 & 23355167.48 & 132.94 \\
\hline 2013 & 181798798 & 23326963.18 & 128.31 \\
\hline 2014 & 133442803 & 32610718.58 & 244.38 \\
\hline 2015 & 200934125 & 26798921.82 & 133.37 \\
\hline
\end{tabular}

Note: ${ }^{*}$ the consolidated data of the amount of insurance agreements and the amount of insurance premiums in 2008 are absent.

Table 2

Dynamics of gross insurance premiums, net insurance premiums and the ratio of insurers' equity to GDP

\begin{tabular}{|c|c|c|c|}
\hline Year & $\begin{array}{c}\text { Gross insurance } \\
\text { premiums, mln UAH }\end{array}$ & $\begin{array}{c}\text { Net insurance pre- } \\
\text { miums, ths UAH }\end{array}$ & $\begin{array}{c}\text { The ratio of insurers' } \\
\text { equity to GDP, \% }\end{array}$ \\
\hline 2005 & 12532.24 & 7161.62 & - \\
\hline 2006 & 13379.18 & 8318.83 & - \\
\hline 2007 & 17224.36 & 11570.38 & - \\
\hline 2008 & 22895.36 & 14868.88 & $2.11^{*}$ \\
\hline 2009 & 19607.18 & 11823.51 & 2.12 \\
\hline 2010 & 22170.34 & 12416.89 & 2.23 \\
\hline 2011 & 21342.56 & 10860.48 & 2.15 \\
\hline 2012 & 19697.90 & 18467.72 & 2.35 \\
\hline 2013 & 26185.17 & 19074.91 & 2.58 \\
\hline 2014 & 24607.51 & 16433.11 & 2.46 \\
\hline 2015 & 27549.42 & 20168.29 & 1.62 \\
\hline
\end{tabular}

Note: * the consolidated data of the amount of insurance agreements and the amount of insurance premiums before 2008 аге absent 
Analysis of the performance of the national non-life insurance market (Table 2) showed the growth in gross and net premiums during 2005-2008 that demonstrates the development of the insurance market in this period. Due to the impact of the financial crisis in 2009 gross and net premiums began to decline. In 2010 the growth of premiums recovered. In 2013 the volume of gross premiums increased to 6487.27 mln UAH equally with the last year. In this year the main factor of the increase in gross premiums was no growth in demand for insurance services, but increase of the need for secondary redistribution of risks through reinsurance. In 2014 gross insurance premiums decreased compared with 2013 to $6.03 \%$ due to the annexation of the Crimea and the deployment of armed conflict in the eastern Ukraine. In 2015 the growth of the gross insurance premiums recovered.

In 2015 the ratio of insurers' equity to GDP reached its critical size, indicating a decrease of financial stability and the ability of the insurance sector to fulfill their obligations to customers. It is worth noting that during 2005 the ratio of insurers' equity to GDP exceeded the ratio of gross insurance premiums to GDP. However, this trend is not due to high capital adequacy of Ukrainian insurers, but low efficiency and control against the formation and use of equity. On the next phase of the study it was analyzed the dynamics of insurance portfolio diversification $\left(I_{I P}\right)$ by the types of insurance according to the formula (1):

$$
I_{I P}=1-\sum_{i}^{n}\left(\frac{N P}{N P}\right)^{2},
$$

where $N P_{I}$ is the amount of net premiums for the $i$-th type of insurance; $N P$ is the total amount of net insurance premiums of the market.

The mentioned indicator (1) is a stimulant that is a high index indicates a high level of diversification of the insurance portfolio.

The dynamics of diversification indexes of insurance portfolio in Ukraine is presented in Fig. 2.

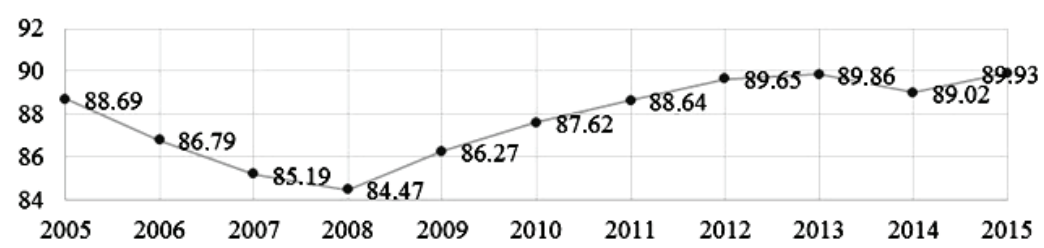

Fig. 2. The dynamics of diversification indexes of insurance portfolio of the non-life insurance companies in Ukraine: - - - the diversification level of the insurance portfolios of insurers in Ukraine, \%

The data presented in Fig. 2 show that the level of diversification of the insurance portfolios of the non-life insurers in Ukraine is high (over 84 \%). During 2005-2008 this figure declined due to dynamic increase in the share of net insurance premiums on insurance of vehicles in the total net insurance premiums of the market. This trend is due to the boom of transport crediting during this period, because an additional condition for borrower to obtain a bank credit to purchase a car is its insurance by the program KASCO. During 2008-2015 the level of diversification of the insurance portfolio is constantly growing, with the exception of 2014. Such dynamics is caused by a decrease in the proportion of net insurance premiums on insurance of transport in the total net insurance premiums and the increase of the shares of net insurance premiums for property insurance and insurance of financial risks.

The important indexes that determine the level of the insurance market development are indicators of its financial safety. In the methodology of calculation of economic security in Ukraine [16] it is proposed five indicators that define financial security of the non-life insurance market. The calculated indicators of financial security of the non-life insurance market are presented in the Table 3.

Table 3

The dynamics of values of financial security indicators of the non-life insurance market in Ukraine

\begin{tabular}{|c|c|c|c|c|c|}
\hline \multirow[b]{2}{*}{ Years } & \multicolumn{5}{|c|}{ The value of indices } \\
\hline & $\begin{array}{c}\text { The } \\
\text { perme- } \\
\text { ability of } \\
\text { insu- } \\
\text { rance, \% }\end{array}$ & $\begin{array}{l}\text { The } \\
\text { index of } \\
\text { insurance } \\
\text { density, } \\
\text { USD }\end{array}$ & $\begin{array}{c}\text { The } \\
\text { level of } \\
\text { insurance } \\
\text { payments, } \\
\%\end{array}$ & $\begin{array}{c}\text { The } \\
\text { share of } \\
\text { premiums } \\
\text { belonging } \\
\text { to non- } \\
\text { resident } \\
\text { reinsurers, } \\
\%\end{array}$ & $\begin{array}{l}\text { The share } \\
\text { of insurance } \\
\text { premiums of } \\
\text { the } 3 \text { largest } \\
\text { insurers in the } \\
\text { total amount } \\
\text { of insurance } \\
\text { premiums, \% }\end{array}$ \\
\hline 2005 & 2.84 & 52.88 & 21.50 & 5.31 & 12.2 \\
\hline 2006 & 2.46 & 56.80 & 27.80 & 4.12 & 12.2 \\
\hline 2007 & 2.39 & 73.55 & 33.40 & 4.31 & 12.6 \\
\hline 2008 & 2.41 & 64.44 & 30.56 & 4.81 & 12.0 \\
\hline 2009 & 2.15 & 53.39 & 34.01 & 6.29 & 11.2 \\
\hline 2010 & 2.05 & 60.84 & 27.28 & 5.14 & 13.6 \\
\hline 2011 & 1.62 & 58.54 & 22.46 & 5.36 & 13.7 \\
\hline 2012 & 1.40 & 54.12 & 25.73 & 6.35 & 9.9 \\
\hline 2013 & 1.80 & 72.14 & 17.20 & 6.09 & 13.5 \\
\hline 2014 & 1.57 & 36.35 & 19.61 & 6.02 & 15.6 \\
\hline 2015 & 1.39 & 26.85 & 27.62 & 8.97 & 14.7 \\
\hline
\end{tabular}

As shown from the Table 3 , the indexes of permeability and density of insurance at the non-life insurance market in Ukraine considerably fall behind from threshold values. As of 01.01.2016 the insurance market provided the redistribution of $1.39 \%$ of GDP, while this figure for developed countries is about $8 \%$. The volume of gross insurance premiums for one person in Ukraine in 2015 was 27 USD while the threshold value is 98 USD. In addition, in 2015 the index of closeness of insurance attained a low level critically that predefined by devaluation of national currency. The low values of density and permeability of insurance on the one hand, indicate potential for further development of the insurance market in Ukraine, and on the other - that the insurance sector is not fully uses its investment potential for economic development.

The low value of insurance claims (less $30 \%$ ), at first glance, suggests about a high solvency of Ukrainian insurers, but international experience shows that this level of claims is typical for undeveloped insurance markets and caused by bad faith insurance companies and the use of 
insurance as a tool of optimization of the tax burden of the other subjects of economic relations.

The indexes of the share of bonuses that belong to non-resident reinsurers and the share of insurance premiums of the 3 largest insurers in the total amount of insurance premiums positively characterize the financial security of the insurance market in Ukraine since their values are within threshold.

The next phase of the study it was analyzed the dynamics of the profitability of the insurance and investment activity of the insurance companies. The profitability of the insurance activity is calculated as the ratio of the income from insurance activities to the amount of gross premiums, and the profitability of investment is calculated as the ratio of profit from investment to the total assets of the insurance market in Ukraine. The initial data and the results of calculation of the profitability of insurers during the 2008-2015 are presented in Table 4.

Table 4

The dynamics of the profitability of the insurance and investment activity of the non-life insurance companies in Ukraine

\begin{tabular}{|c|c|c|c|c|c|c|}
\hline \multirow{2}{*}{ Year } & \multicolumn{2}{|c|}{$\begin{array}{l}\text { The total amount } \\
\text { of income by the } \\
\text { types of activity, } \\
\text { mln UAH: }\end{array}$} & \multirow{2}{*}{$\begin{array}{l}\text { The total } \\
\text { assets, } \\
\text { mln UAH }\end{array}$} & \multirow{2}{*}{$\begin{array}{l}\text { The gross } \\
\text { insurance } \\
\text { premiums, } \\
\text { mln UAH }\end{array}$} & \multicolumn{2}{|c|}{$\begin{array}{c}\text { The profitability } \\
\text { of insurers by } \\
\text { the types of } \\
\text { activity, \%: }\end{array}$} \\
\hline & $\begin{array}{l}\text { insu- } \\
\text { rance } \\
\text { activity }\end{array}$ & $\begin{array}{l}\text { invest- } \\
\text { ment } \\
\text { activity }\end{array}$ & & & $\begin{array}{l}\text { insu- } \\
\text { rance } \\
\text { activity }\end{array}$ & $\begin{array}{l}\text { invest- } \\
\text { ment } \\
\text { activity }\end{array}$ \\
\hline 2008* & 2196.88 & 618.14 & 28058.95 & 22895.36 & 9.60 & 2.20 \\
\hline 2009 & 270.56 & 715.90 & 23797.90 & 19607.18 & 1.38 & 3.01 \\
\hline 2010 & 945.41 & 688.74 & 25692.95 & 22170.34 & 4.26 & 2.68 \\
\hline 2011 & 647.49 & -71.25 & 39814.75 & 21342.56 & 3.03 & -0.18 \\
\hline 2012 & 6487.32 & 853.80 & 44933.03 & 19697.90 & 32.93 & 1.90 \\
\hline 2013 & 7004.79 & 898.35 & 55005.69 & 26185.17 & 26.75 & 1.63 \\
\hline 2014 & 3692.67 & 573.79 & 58946.76 & 24607.51 & 15.01 & 0.97 \\
\hline 2015 & 1937.93 & 726.26 & 49976.48 & 27549.42 & 7.03 & 1.45 \\
\hline
\end{tabular}

Note: ${ }^{*}$ the consolidated data of the amount of equity of the insurance companies are absent.

The data from the Table 4 show that throughout the analyzed period, except 2009, the profitability of insurance activity in Ukraine significantly higher than the profitability of investment activity. The low profitability of investment activity was caused by holding insurers conservative investment policy by placing assets in financial instruments with the low income and the low risk.

To eliminate the multicollinearity between selected indicators assessing the level of the insurance market it was built the correlation matrix. The lowest value of strong communication between distress indicators are pair correlation coefficient of 0.7 [17]. As shown the calculation results, a number of selected indicators have a high correlation between each other.

After eliminating the effect of the multicollinearity it was left ten indicators that were used to build taxonomic index of development, including: the total amount of responsibility for insurance agreements (X1), the average amount covered on one insurance contract (X2), the amount of net insurance premiums (X3), the ratio of insurers' equity to GDP (X4), the level of diversification of insurance portfolios of insurers by the types of insurance (X5), insurance density (X6), the level of claims (X7), the share of insurance premiums of the 3 largest insurers in the total amount of insurance premiums (X8), the profitability of insurance (X9) and the profitability of investment (X10).

The next step in the work included the aggregating these ten indicators for taxonomy method whereby the value of a property is the sum of its parts. As the selected indicators have different units, the taxonomic analysis needs to bring them to one dimension, i. e. normalization [17].

Among the indicators that characterize the level of the insurance market, it was highlighted the stimulators, the quantitative growth of which positively affects the efficiency of activity, and the destimulators, the low value of which is better for the development of the insurance market. In the research the destimulators is only the index of the share of insurance premiums of the 3 largest insurers in the total amount of insurance premiums, all other indexes are stimulators.

After determination of indexes-stimulators and destimulators the standard point was built $p_{0}\left(x_{01}, x_{02}, \ldots x_{0 j}, \ldots x_{0 m}\right)$. The standard point in this study is an artificial state of the insurance market, which is characterized by the best value for each of the indicators throughout the analyzed period. For indexes-stimulators the standard point accounts as $x_{0 j}=\max x_{i j}$, and for destimulators - as $x_{0 j}=\min x_{i j}$. For indicators with normative values (the density of insurance, the level of insurance claims, the share of insurance premiums of the 3 largest insurers in the total amount of insurance premiums), the normalized values of these indicators are selected as the standard values.

After building the standard point it was calculated distances between the separate indexes that characterize the objects of analysis, and the standard point according to the formula of Euclid's distance [17]:

$$
d_{0 i}=\sqrt{\sum_{j=1}^{m}\left(x_{i j}-x_{0 j}\right)^{2}},
$$

where $d_{0 i}$ is the distance between the values of standardized indicators and the standard point; $x_{0 j}$ is the standardized value of the standard point of the $i$-th indicator.

The analysis of the deviation of the actual value of the index from the standard point allows to determine the reserve of increase of the level of development of the insurance market in a certain direction.

The immediate determination of the integral index of the insurance market made according to the formula:

$$
K_{i}=1-\frac{d_{0 i}}{d}, d=\bar{d}_{0}+2 \sigma_{0},
$$

where

$$
\bar{d}_{0}=\frac{\sum_{i=1}^{n} d_{0 i}}{n}
$$

is the arithmetic mean of the Euclid's distances between objects and the standard point;

$$
\sigma=\sqrt{\frac{\sum_{i=1}^{n}\left(d_{0 i}-\bar{d}_{0}\right)^{2}}{n}}
$$

is the standard deviation of the Euclid's distances between objects and the standard point. 
The results of calculation the integral indicator of development of the insurance market during 2008-2015 are presented in Fig. 3.

In the period from 2008 to 2010 it was the gradual recovery of the non-life insurance market after the financial crisis, as evidenced by the growth of taxonomic index (Fig. 3). In 2011 the integral indicator was the lowest value. This is because for the entire reporting period at that time it was the lowest values of the overall responsibility for the insurance agreements, the average insured sum for one insurance contract, the net insurance premiums, the profitability of investment, the profitability of insurance was also low. However, already in 2012, the indicator of the development of the insurance market reached its maximum level by restoring growth of the net insurance premiums and insurance sums, as well as by a high value of the return on insurance activity. From 2013 to 2015 it was traced the rapid fall of the insurance market in Ukraine, due to the economic downturn, decline in purchasing power of the currency and the goodness of people.

For the qualitative interpretation of the results of an integrated assessment of the insurance market development level in Ukraine it was used the scale developed by the law of Fibonacci. According to this law changes most likely take place at the level of $38.2 \%$ and $61.8 \%$ [18]. The difference between maximum and minimum values of the scale in this case is $1-0=1$. After multiplying this difference at 0.382 and 0.618 , and deducting the amounts received from the maximum value it was received the value of the scale, in which according to the law of Fibonacci changes most likely take place. As a result of construction of the scale it was received three ranges of the integral indicator of the insurance market development: low [0;0.382), average $[0.382 ; 0.618)$ and high $[0.618 ; 1]$.

On the basis of the scale we can conclude that during the analyzed period (2008-2015) the integral indicator of the insurance market development was not high. Only in 2010 and 2012 the insurance market development in Ukraine has reached average level. At all other times the activity of the insurance market was low. tives of the Solvency II, which are directed to identify problems in the activities of insurers in the early stages of their appearance and prevent the crisis in the insurance market.

\section{SWOT analysis of research results}

Strengths. The strength of the research is to analyze performance of the insurance market by 2005-2015 and develop integral indicator of it development using the method of taxonomy.

Weaknesses. The weak point is that the work is not carried out a comparative analysis of the impact of domestic and foreign insurance companies on the development of the insurance market in Ukraine.

Opportunities. Opportunities for future research are to develop methodological support for the prediction of the insurance market development in Ukraine in the short and long term.

Threats. Threats to the results of the research is that the development of the insurance market depends on general economic conditions and the development of the real economy, new types of factors should be consider when building a methodology for assessing the level of development of the insurance market.

\section{Conclusions}

1. Activities of the non-life insurance companies depend on the development of the real sector of the economy and welfare.

2. The non-life insurance market in Ukraine is on the stage of development. In recent years, there is a negative trend of falling the ratio of gross insurance premiums to GDP. This indicates a decrease in demand for insurance services in an economic downturn. Among the positive trends that characterize the development of the insurance market in Ukraine, the authors highlighted growing the diversification of the insurance portfolio of insurers by personal insurance.

3. For assessment of the non-life insurance market development level there were selected the indexes of amount of insurance companies, the amount of the insurance contracts and the volume of responsibility after them, the middle amount covered on one contract of insurance, the volume of gross and clean insurance bonuses, the level of diversification of insurance brief-cases of insurers, the strength of the insurance market, profitability of insurance and investment activity of insurance companies.

Multicollinearity between selected parameters was

As a result of scaling of the indicator of the development it was found that the insurance market is very dependent on the overall economic condition of the state, because during the recession the need for insurance protection goes by the wayside. In addition, the economic fluctuations influence on the ability of the insurer companies to fulfill their obligations, which adversely affects on the level of consumer confidence in the insurance market. In such circumstances before public authorities there is a need to improve tools of supervisory activities that would help to improve the financial stability and integrity of domestic insurers. These instruments include the European Direceliminated using correlation analysis.

5. The integral indicator of the insurance market development is calculated using taxonomic analysis. For the qualitative interpretation of the results of an integrated assessment of the insurance market development level in Ukraine it was used the scale developed by the law of Fibonacci. Based on the scale authors concluded that during the analyzed period the integral indicator of the insurance market development was not high. Only in 2010 and 2012 the insurance market development in Ukraine has reached average level. At all other times the activity of the insurance market was low. 


\section{References}

1. Konsolidovani zvitni dani [Electronic resource] // National Commission for Regulation of Financial Services Markets. Available at: \www/URL: https://nfp.gov.ua/content/konsolidovani-zvitni-dani.html

2. 2016 European insurance outlook [Electronic resource] // Ernst \& Young Global. - Available at: \www/URL: http://www. ey.com/Publication/vwLUAssets/EY-2016-european-insuranceoutlook/\$FILE/EY-2016-european-insurance-outlook.pdf

3. Insurance Europe's Annual Report 2015-2016 [Electronic resource] // Insurance Europe. - Available at: \www/URL: https://www.insuranceeurope.eu/sites/default/files/attachments/Annual\%20Report\%202015-2016.pdf

4. Annual Report 2015 [Electronic resource] // EIOPA. - Available at: \www/URL: https://eiopa.europa.eu/Publications/Reports/ EIOPA\%20Annual\%20Report\%202015.pdf\#search=EIOPA\%20 annual\%20report

5. The Insurance Industry's Contribution to Community Development [Electronic resource] // Insurance Information Institute. Available at: \www/URL: http://www.iii.org/sites/default/files/ docs/pdf/impact_win16.pdf

6. Achkasova, S. The governmental regulation of the insurance market in the European integration processes [Text] / S. Achkasova // Economic Annals-XXI. - 2015. - № 7-8 (2). - P. 49-52.

7. Vasechko, L. Current issues of insurance market of Ukraine [Text] L. Vasechko // Ekonomichnyi prostir. - 2016. - № 109. P. $146-154$

8. Kozmenko, O. V. Strakhovyi rynok Ukrainy u konteksti staloho rozvytku [Text]: Monograph / O. V. Kozmenko. - Sumy: DVNZ «UABS NBU», 2008. - 350 p.

9. Plysa, V. Y. The strategy of post-crisis development of insurance market in Ukraine [Text] / V. Y. Plysa // Financial Space. - 2011. - № 3 (3). - P. 90-96.

10. Yukhumenko, V. Insurance industry: world trends and prospects in Ukraine [Text] / V. Yukhumenko // Investytsiyi: praktyka ta dosvid. - 2016. - № 3. - P. 44-48.

11. Alhassan, A. L. Insurance market development and economic growth [Text] / A. L. Alhassan, N. Biekpe // International Journal of Social Economics. - 2016. - Vol. 43, № 3. - P. 321-339. doi:10.1108/ijse-09-2014-0182

12. Outreville, J. F. The Relationship Between Insurance and Economic Development: 85 Empirical Papers for a Review of the Literature [Text] / J. F. Outreville // Risk Management and Insurance Review. - 2012. - Vol. 16, № 1. - P. 71-122. doi:10.1111/j.1540-6296.2012.01219.x

13. Chang, C. H. Non-Linearity Between Life Insurance and Economic Development: A Revisited Approach [Text] / C. H. Chang, C. C. Lee // The Geneva Risk and Insurance Review. - 2011. Vol. 37, № 2. - P. 223-257. doi:10.1057/grir.2011.10
14. Kozarevic, S. Efficiency of the transition of the insurance markets in south-eastern European post-communist countries [Text] S. Kozarevic, L. Peressin, G. Valentinus // South-Eastern Europe Journal of Economics. - 2013. - № 2. - P. 139-164.

15. Zyka, E. Factors affecting the insurance sector development: Evidence from Albania [Text] / E. Zyka, E. Myftaraj // The Romanian Economic Journal. - 2014. - № 51. - P. 171-188.

16. Pro zatverdzhennia Metodychnykh rekomendatsii shchodo rozrakhunku rivnia ekonomichnoi bezpeky Ukrainy [Electronic resource]: Decree of the Ministry of Economic Development and Trade of Ukraine from 29.10.2013 № 1277. - Available at: \www/URL: http://cct.com.ua/2013/29.10.2013_1277.htm

17. Hurianova, L S Metodychni rekomendatsii do vykonannia laboratornykh robit $\mathrm{z}$ navchalnoi dystsypliny «Matematychni metody i modeli doslidzhennia ekonomichnykh protsesiv» [Text] / L. S. Hurianova, O. A. Serhiienko, O. V. Nikiforova et al. Kharkiv: KhNEU, 2012. - 64 p.

18. Metod Fibonachchi [Electronic resource]. - Available at: \www/ URL: http://math.semestr.ru/optim/fibonacci.php

\section{УСОВЕРШЕНСТВОВАНИЕ ОЦЕНКИ УРОВНЯ РАЗВИТИЯ СТРАХОВОГО РЫНКА В УКРАИНЕ}

Рассмотрены особенности функционирования страховых компаний в Украине, осуществляющих страхование иное, чем страхование жизни. Проведен анализ национального страхового рынка за 2005-2015 гг., что позволило определить основные проблемы его развития. Для оценки уровня развития страхового рынка избрано 14 показателей. С использованием корреляционного анализа устранена мультиколлинеарность между выбранными показателями. Рассчитан интегральный показатель уровня развития страхового рынка Украины с применением метода таксономии.

ключевые слова: страховой рынок, финансовая безопасность, страховой портфель, рентабельность страховой деятельности.

Opeshko Nataliya, PhD, Lecturer, Department of Financial Services Management, Simon Kuznets Kharkiv National University of Economics, Ukraine, e-mail: nopeshko@mail.ru, ORCID: http://orcid.org/ 0000-0001-6611-3401

Hontar Daria, PhD, Lecturer, Department of Banking, Simon Kuznets Kharkiv National University of Economics, Ukraine, e-mail: ddgontar@i.ua, ORCID: http://orcid.org/0000-0001-5416-9328

Kovalchuk Viktoriia, PhD, Lecturer, Department of Finance, Simon Kuznets Kharkiv National University of Economics, Ukraine, e-mail: kovalchuk.v.a@ukr.net, ORCID: http://orcid.org/0000-0001-5793-4611

\section{Minkova 0. Kalinichenko A., Gorb 0.}

\section{RESEARCH OF ORGANIC AGRICULTURAL PRODUCTION SUPPORT IN POLAND}

Представлено результати аналізу функиіонування польської системи виробництва органічної сільськогосподарської продукції. Висвітлено основні особливості реалізації багаторівневої системи підтримки розвитку органічного руху. Розглянуто локальну спещифіку та умови функціонування екологічних сільгоспвиробників у Польщі.

Ключові слова: органічне сільськогосподарське виробництво, польський досвід, екологічно безпечна продукція.

\section{Introduction}

In the international community, organic farming practices have become increasingly recognized over the past decades as a management system that balances the productivity of the agroecosystem and the restoration of the environment, as well as the integrated persistence of anthropogenic ecosystems in accordance with the concept of sustainable development. 